\title{
Mempertanyakan Pemrofilan Kriminal sebagai Sebuah Ilmu Psikologis
}

\author{
Jun e m a n \\ Himpunan Psikologi Indonesia Wilayah D.K.I. Jakarta
}

\begin{abstract}
Psychology contributes to criminal profiling process. Unfortunately, after intensive review on latest research findings, it is detected that most criminal profiling process is not based on strong scientific assumptions. This article explains the reasons why criminal profiling is quite a problem for psychology as a science. The author proposes several ideas to overcome this problem. The first idea is about the accurate understanding of criminal profiling scientific status. The science-pseudoscience-non science dichotomy and protoscience-science spectrum will support this understanding. The second idea is that there are some things to be considered for criminal profiling in order to be a prestigious discipline and be used scientifically appropriate by scientists and practitioners of forensic psychology and criminology.
\end{abstract}

Keywords: criminal profiling, crime action profiling, offender profiling, crime scene, forensic psychology, signature behavior, pseudoscience, protoscience, noumena, organized/disorganized behavior, computerized criminal profiling

Sejak awal Maret 2009, media massa di Indonesia ramai memberitakan kasus kematian David Hartanto Widjaja beserta perkembangan penanganannya oleh Kepolisian dan Peradilan Singapura, antara lain Kompas.com ("Penyebab tewasnya," 2009), sebagai berikut:

.... David Hartanto Widjaja, mahasiswa asal Jakarta, Senin (2/3), ditemukan tewas dalam posisi tertelungkup di antara rumput dan beton tempat jalan kaki pada selasar NTU (Nanyang Technological University). Kematian mantan duta Indonesia untuk olimpiade matematika menimbulkan kontroversi, menyusul pernyataan segera dari NTU bahwa dia bunuh diri dengan meloncat dari lantai IV di kampusnya. NTU. Seperti dipublikasikan media Singapura dan banyak dikutip media di dalam negeri pula, menyebut, sebelum melompat, David yang sedang tertekan kejiwaaan akibat beasiswanya dihentikan, menyayat pergelangan tangan sendiri, setelah menikam dosen pembimbing tugas akhirnya di Jurusan Teknik Elektro NTU, Prof Chan, di satu ruangan lantai V. Namun, beberapa rekan David secara terbuka di beberapa milis menyatakan, pernyataan NTU itu adalah janggal antara lain karena David mereka kenal periang, bukan tipe orang yang mudah dilanda stres. Mereka mengharapkan aparat penegak hukum di Singapura benar-benar menyelidik kasus tersebut sebab bukan tidak mungkin David adalah korban, bukan pelaku kriminal apalagi kemudian bunuh diri ....

Di samping itu, pada sebuah forum online yang memperbincangkan kasus ini pada The Strait Times Discussion Board, seorang peserta diskusi dengan nickname shunhua09, menulis ("Student stabs," 2009), sebagai berikut: 
.... Well, if I were to have my way and conclude what I believe happened. I would say: During the routine discussion, the Prof told David that he isn't making good progress with his FYP. Coupled with the fact that he got his scholarship revoked before that, in a fit of anger and displeasure, David could have threatened Prof. I believe this action, IS NOT PRE-MEDIATED and NOT PRE-PLANNED. In that case, David did so in a moment of anxiety. Hence, justifying the fact that he could have been calmed the day before and was his usual self, until the Prof talked to him, of which, the contents of the conversation might have triggered such a response. In the ensuing struggle that followed, both parties were injure. (Note: I believe its a struggle that cause the injuries of both parties, and NOT a planned offensive by David.) Seeing the damage done, I believe David hurriedly left the scene entirely due to fear, and not a planned escape. He stumbled and climbed over the ledge onto the bridge and sat down, probably because he thought it was safe there. However, due to loss of blood and his panic state, he fell off the bridge. That is what I believe....

Dari seluruh cuplikan di atas, diketahui adanya sejumlah pertanyaan yang hendak dijawab, seperti: (a) apakah David bunuh diri? (Bila ya/tidak, mengapakah? Bagaimanakah?), (b) apakah David membunuh profesornya?, (c) apakah David dibunuh oleh profesornya?, (d) apakah David mengalami kecelakaan?, dan mungkin masih banyak pertanyaan lainnya. Sampai dengan waktu artikel ini ditulis, sejumlah pertanyaan tersebut belum juga terjawab dan kasusnya masih diproses oleh aparat hukum di Singapura. Namun, hal yang dilakukan oleh shunhua09 merupakan representasi dari upaya intuitif manusia untuk mengkonstruksi "teori-teori" kausal mengenai perilaku manusia. Upaya tersebut dinamai oleh Fritz Heider (1958) sebagai naïve psychology. Menurut Heider, setiap orang adalah "psikolog yang naif".

Tulisan ini tidak hendak menganalisis kasus David Hartanto dengan teori psikologi naif maupun dengan teori-teori atribusi kausal dari psikologi sosial, melainkan akan mengkaji secara kritis keilmiahan sebuah disiplin dalam psikologi forensik yang paling mungkin mendiskusikan dan menemukan jawab atas sejumlah pertanyaan di atas-yakni: pemrofilan kriminal. Hal ini menjadi semakin penting karena banyak kasus-utamanya kasus-kasus kriminal-yang menampakkan urgensi untuk menggunakan disiplin ini, khususnya di Kepolisian, dalam rangka menyelesaikan kasus-kasus tersebut.

\section{Apakah Pemrofilan Kriminal Itu?}

Pemrofilan kriminal (criminal profiling) merupakan pekerjaan menyimpulkan rincian ciri-ciri fisik (tinggi dan berat badan, cacat rupa, dan sebagainya), demografis (usia, jenis kelamin, latar belakang etnis, dan sebagainya), dan keperilakuan (kepribadian, termasuk motivasi, gaya hidup, fantasi, proses seleksi korban, serta perilaku sebelum dan prediksi perilaku sesudah tindak kejahatan) dari kemungkinan pelaku kejahatan berdasarkan aksi-aksinya pada scene kejahatan (O'Toole, 1999; Snook, Gendreau, Bennell, \& Taylor, 2008). Scene kejahatan meliputi tempattempat potensial sejauh bukti dari sebuah tindak kriminal-misalnya, penculikan-dapat ditemukan, yang terdiri dari scene kejahatan primer dan sekunder (Horswell, 2004). Scene kejahatan primer adalah wilayah, tempat, atau sesuatu di mana insiden terjadi atau di mana sebagian besar atau konsentrasi yang tinggi dari bukti-bukti kejahatan ditemukan (misalnya, tempat terjadinya 
penculikan). Scene kejahatan sekunder adalah tempat-tempat atau benda-benda di mana bukti-bukti yang berkaitan dengan insiden dapat ditemukan (misalnya, alat transportasi dan rute akses yang digunakan pelaku kejahatan untuk membawa korban penculikan ke lokasi lain). Data scene kejahatan dapat juga diambil dari foto-foto, laporan-laporan penyelidik, hasil otopsi, dan sebagainya, yang akan menyusun suatu profil kriminal (criminal profile)—termasuk karier kriminal (criminal career)—dari pelaku kejahatan.

Keseluruhan proses pemrofilan kriminal mirip dengan proses pengumpulan data dalam penelitian kualitatif yang dikemukakan Koentjoro (2008). Menurutnya, ada empat jenis sumber data penelitian kualitatif, yakni subjek, informan, written documents dan unwritten documents. Dalam prosesnya, penggalian data/informasi dalam penelitian kualitatif diibaratkan sebagai sebuah simfoni (Koentjoro, 2008). Dalam hal ini, potongan atau penggalan data yang diperoleh peneliti kualitatif ibarat bunyi biola atau bus atau drum yang ketika dibunyikan mungkin tidak memiliki makna apapun; namun apabila "bunyi-bunyian" tersebut dirangkaikan dengan data yang lain, barulah mereka mempunyai makna. Jadi, dapat disimpulkan bahwa pelaku pemrofilan kriminal atau pemrofil (criminal profiler) pada hakikatnya adalah seorang yang bekerja sebagai "peneliti kualitatif".

Turvey (2008) membedakan antara pemrofilan kriminal induktif dan deduktif. Pemrofilan kriminal induktif mencakup generalisasi berdasarkan sejumlah kecil individu atau peristiwa dan/atau penalaran statistik (pererataan, ekstrapolasi, korelasi, dan sebagainya). Metode ini memiliki kelemahan karena - berlawanan dengan asumsi statistik — tidak ada dua kasus yang persis sama; pelaku kriminal berpikir secara berbeda dari kebanyakan orang, pun perilaku memiliki makna-makna yang berbeda antar-kultur dan wilayah. Dalam metode deduktif, pemrofil menghasilkan sebuah profil berdasarkan eksaminasi forensik serta rekonstruksi keperilakuan yang hati-hati terhadap scene kejahatan. Dalam hal ini, penekanannya antara lain pada pengetahuan-diri pemrofil (pengatasan bias transferensi) dan kemampuan berpikir kritis pemrofil, beserta kemampuan pemrofil untuk memahami kebutuhan-kebutuhan yang sedang dipuaskan oleh setiap perilaku dari pelaku kejahatan serta pola-pola pelaku kejahatan. Kategorisasi Turvey di atas memiliki kesepadanan dengan orientasi statistik dan orientasi klinis yang dirangkum oleh Snook, Cullen, Bennell, Taylor, dan Gendreau (2008) berdasarkan sejumlah kajian kepustakaan. Dalam pemrofilan kriminal yang berorientasi statistik, pemrofil melakukan penilaian berdasarkan analisisnya terhadap para pelaku kejahatan yang sebelumnya telah lebih dahulu melakukan tindakan kriminal; dalam hal ini mereka dibandingkan keserupaannya dengan pelaku kejahatan yang sedang diinvestigasi saat ini. Dalam orientasi klinis, pemrofil mengambil inspirasi/gagasan pemrofilan dari pelatihan, pengetahuan, dan pengalaman yang dimilikinya.

Proses-proses dan istilah-istilah spesifik yang berkaitan dengan pemrofilan kriminal sangat bergantung pada latar belakang profesi dan pelatihan dari pemrofil (Snook, Gendreau, et al., 2008). Dalam lingkup psikologi forensik, misalnya, digunakan istilah-istilah antara lain, sebagai berikut: psychological profiling, offender profiling, criminal personality profiling (Webb, 2006). Istilah-istilah tersebut secara umum menggambarkan bahwa pemrofil (criminal profiler) meneliti kandungan "psikopatologi" yang terkandung pada scene kejahatan-yang terdiri atas indikator- 
indikator keperilakuan dan psikologis sebagai hasil dari interaksi fisik, seksual, dan verbal antara pelaku dan korbannya, dalam hal mana indikator-indikator ini menyusun sebuah "cerita" yang “ditulis" oleh pelaku, korban dan interaksi uniknya (O'Toole, 1999).

\section{Kontribusi Psikologi}

Pemrofilan kriminal dalam lingkup kerja FBI (Federal Bureau of Investigation) di Amerika Serikat termasuk dalam unit kerja Behavioral Analysis Unit (BAU), dalam mana agen-agen yang terseleksi mengikuti kuliah-kuliah yang dimulai dari kuliah mengenai psikologi dan selanjutnya kuliah-kuliah spesifik (Hits dalam Ramsland, 2008), dengan urutan sebagai berikut: Basic Psychology, Criminal Psychology, Forensic Science, Body Recovery, Criminal Investigative Analysis, Death Investigation, Threat Assessment, Statement/document Analysis, Crimes Against Children, Child Abduction and Homicide, Sexual Victimization of Children / Internet Issues, Interview and Interrogation Procedures, Serial Murder. Sejak setahun yang lalu, dalam sebuah petisi yang diajukan kepada American Psychological Association dalam rangka pengakuan profesi Psikologi Kepolisian, pemrofilan kriminal telah diusulkan dalam domain "operational support" dari kompetensi utama psikologi kepolisian ("Petition for," 2008).

Dimulainya rangkaian kuliah BAU FBI dengan subjek psikologi dan diusulkannya pemrofilan kriminal sebagai salah satu kompetensi khas psikologi kepolisian di atas tidak mengherankan, karena, seperti dinyatakan Turvey (2008: 125), bahwa aspek signifikan dari pemrofilan kriminal adalah pengetahuan mengenai perilaku manusia dan keahlian untuk menginterpretasikan maknamakna dari perilaku tersebut; sementara itu, ahli-ahli psikologi dan psikiatri forensik memiliki pemahaman dan pelatihan yang khas dalam proses-proses mental, fisiologi, perilaku manusia, dan psikopatologi. Psikologi lingkungan juga berperan, sebagaimana ditunjukkan David Canter (2003) — seorang teoris psikologi tempat (psychology of place), dalam bukunya, "Mapping Murder: The Secrets of Geographical Profiling". Canter menunjukkan relasi antara psikologi lingkungan dengan kejahatan, antara lain dengan memperlihatkan secara rinci bagaimana ruang dan waktu berkaitan dengan aktivitas kriminal. Selain alasan-alasan di atas, kompetensi psikologis juga diperlukan untuk menyimpulkan signature behavior yang dibedakan dari modus operandi pelaku kejahatan. Modus operandi mengindikasikan pendidikan dan pelatihan teknis yang dimiliki pelaku kejahatan serta tingkat pengalaman pelaku kejahatan dalam melakukan tindak kriminal dan dalam menghadapi sistem peradilan; namun signature behaviors merupakan setiap tindakan yang dilakukan pelaku kejahatan yang tidak harus menjadi syarat perlu bagi sebuah tindak kriminal, namun menyatakan kebutuhan psikologis atau emosional pelakunya (seperti: rasa tamak, balas dendam, rasa marah, mencari untung, ingin berbuat sadis atau perilaku tak wajar lainnya, hasrat berkuasa, dan sebagainya) (Rogers, 2003; Turvey, 2008). Dalam ilmu forensik komputer, contoh modus operandi adalah menjalankan skrip milik orang lain atau memprogram skrip sendiri yang digunakan untuk menyerang atau merusak sebuah komputer; sedangkan signature behavior lebih terpersonalisasi, seperti menandai files atau kode program dengan nama julukan (nickname)-nya sendiri (Rogers, 2003).

Oleh karena hal-hal tersebut, profesi kesehatan mental seperti ahli psikologi dapat bekerja 
dengan baik dalam proses-proses pemrofilan kriminal sejauh mereka telah memperoleh pula pendidikan yang terkait dengan investigasi dan ilmu-ilmu forensik (Turvey, 2008), demikian pula ahli forensik atau pun kriminolog yang telah memperoleh pendidikan psikologi. Terdapat dua sumbangan besar psikologi dalam penelitian pemrofilan kriminal, sebagai berikut (Winerman, 2004):

Pertama, offender profiling, merupakan salah satu bentuk dari psikologi investigatif yang berasal dari karya-karya seorang ahli psikologi terapan David Canter, pendiri psikologi investigatif pada awal 1990-an. Seluruh penyimpulan dalam pemrofilan ini berbasiskan penelitian empiris (atau "psikologi akademis") dan ditimbang oleh rekan sejawat (peer-reviewed). Sebagai contoh, Canter et al. (dalam Winerman, 2004) pernah menganalisis data scene kejahatan dari 100 pembunuhan beruntun yang mengindikasikan bahwa seluruh pembunuhan menunjukkan derajat organisasi perilaku tertentu, atau dengan perkataan lain: tidak bersifat dikotomis (organized atau disorganized). Perilaku terorganisasi/terencana — seperti pemosisian atau penyembunyian tubuh korban-merupakan "variabel-variabel inti" (core variables) yang cenderung muncul dalam kebanyakan kasus dan berada bersama dengan variabel-variabel lainnya. Namun, yang membedakan antara pembunuh yang satu dengan yang lainnya bukanlah jenis-jenis perilaku disorganisasi/tak terencana-nya, melainkan cara pelaku berinteraksi dengan korbannya yang terbagi menjadi kategori-kategori: melalui kontrol seksual, melalui mutilasi, eksekusi, atau perampasan. Dalam studi yang lain, Canter et al. (dalam Winerman, 2004), mengumpulkan data scene kejahatan dari 112 kasus perkosaan. Mereka menemukan bahwa hal yang membedakan satu pemerkosa dengan pemerkosa lain bukanlah jenis-jenis pencabulan seksual dan penyerangan fisik (dengan demikian, hal-hal ini tergolong variabel-variabel inti), melainkan interaksi-interaksi yang bersifat nonfisik (misalnya, apakah pelaku mencuri dari korban, meminta maaf kepada korban, dan sebagainya). Canter memberikan porsi peran yang tidak signifikan kepada "pengalaman investigatif", yakni pengalaman yang dikembangkan oleh agen-agen penegak hukum dalam melakukan offender profiling. Menurutnya, para psikolog seyogianya mengumpulkan data dari dasar (grounded theory).

Kedua, crime action profiling, yang berbasiskan pengetahuan yang dikembangkan oleh para psikolog forensik, psikiater, dan kriminolog berdasarkan sejumlah besar studi terhadap pelaku pembunuhan serial, pemerkosa, dan pelaku pembakaran. Model-model yang digunakan sebagai panduan bagi pemrofilan terhadap aksi kriminal, menurut Kocsis (Winerman, 2004) serupa dengan wawancara terstruktur yang digunakan oleh para psikolog klinis untuk membuat diagnosis klinis. Dalam hal ini, pertanyaan-pertanyaan yang perlu dikembangkan dalam rangka eksaminasi sistematis sebelum membangun prinsip-prinsip pemrofilan, antara lain, sebagai berikut (Kocsis dalam Winerman, 2004): "Jenis informasi seperti apa yang dikandung, atau seyogianya dikandung, oleh sebuah profil? Jenis material kasus apa yang Anda perlukan untuk mengonstruksi sebuah profil? Bagaimana keberadaan atau ketidakberadaan material mempengaruhi akurasi sebuah profil?" Selanjutnya, menurut Kocsis (2006), profil kriminal yang dihasilkan oleh pemrofilan kriminal dapat dibedakan dengan profil kepribadian (personality profile) atau profil psikologis (psychological profile). Kocsis menegaskan bahwa-berkebalikan dengan pemrofilan kepribadian 
atau pemrofilan psikologis yang seringkali melibatkan evaluasi dan diagnosis terhadap pasien kriminal (criminal patient) — pemrofilan kriminal tidak melakukan eksaminasi atau pemeriksaan terhadap pasien kriminal melainkan terhadap aksi kriminal itu sendiri, yang kemudian dianalisis dan diinterpretasikan bukti keperilakuannya guna menghasilkan gambaran individu yang diduga melakukan perilaku tersebut. Dalam kaitan dengan ini, Cook dan Hinman (1999) menjelaskan bahwa, "Specific suspects, who have already been identified, are not profiled .... The focus of the analysis or profile is the behavior of the perpetrator or perpetrators within the crime scene."

\section{Pseudo- atau Protoscience?}

Sekalipun di dunia cukup populer aplikasinya, Snook, Cullen, et al. (2008) mengingatkan bahwa pemrofilan kriminal telah terjebak dalam praktek pseudoscientific, dalam hal mana, meskipun penggunaannya didukung oleh petugas kepolisian dan profesi kesehatan mental, proses yang dijalani dan hasil yang diperoleh merupakan "ilusi" belaka. Bila hal ini benar, maka status ilmiah pemrofilan kriminal dapat disejajarkan dengan pseudosciece dan praktek pseudoscientific lainnya, seperti palmistri dan astrologi (Sarwono, 2000), senam otak/brain gym (Goldacre, 2006), The Doman-Delacato Patterning Treatment for Brain Damage (National Council Against Health Fraud, 2001), terapi EMDR/Eye Movement Desensitization and Reprocessing (Carrol, 2009; Cuvelier, 2001), Craniosacral Therapy (Hartman, \& Norton, 2002), Thought Field Therapy (TFT)/Emotional Freedom Technique (EFT) (Barrett, 2003), analisis sidik jari (fingerprint analysis) (Sherrer, 2004), dan sebagainya.

Batasan ilmu semu (pseudoscience) menurut Sarwono (2000) sebagai berikut:

... ada pula sarjana-sarjana yang mengajukan teori-teori mengenai psikologi yang sesungguhnya tidak didasarkan pada metode-metode yang benar-benar ilmiah. Yang mereka lakukan adalah menyusun pengetahuan-pengetahuan yang sudah ada dan bisa dikumpulkan mengenai gejala-gejala kejiwaan dan mensistematiskan pengetahuan-pengetahuan itu. Karena pengetahuan-pengetahuan itu sudah tersusun secara sistematis, maka tampaknya seperti sudah ilmiah, padahal tidak ada yang bisa dibuktikan secara empiris metodologis. Karena itu mereka digolongkan sebagai orang-orang yang menggunakan ilmu semu untuk menerangkan gejala kejiwaan. 


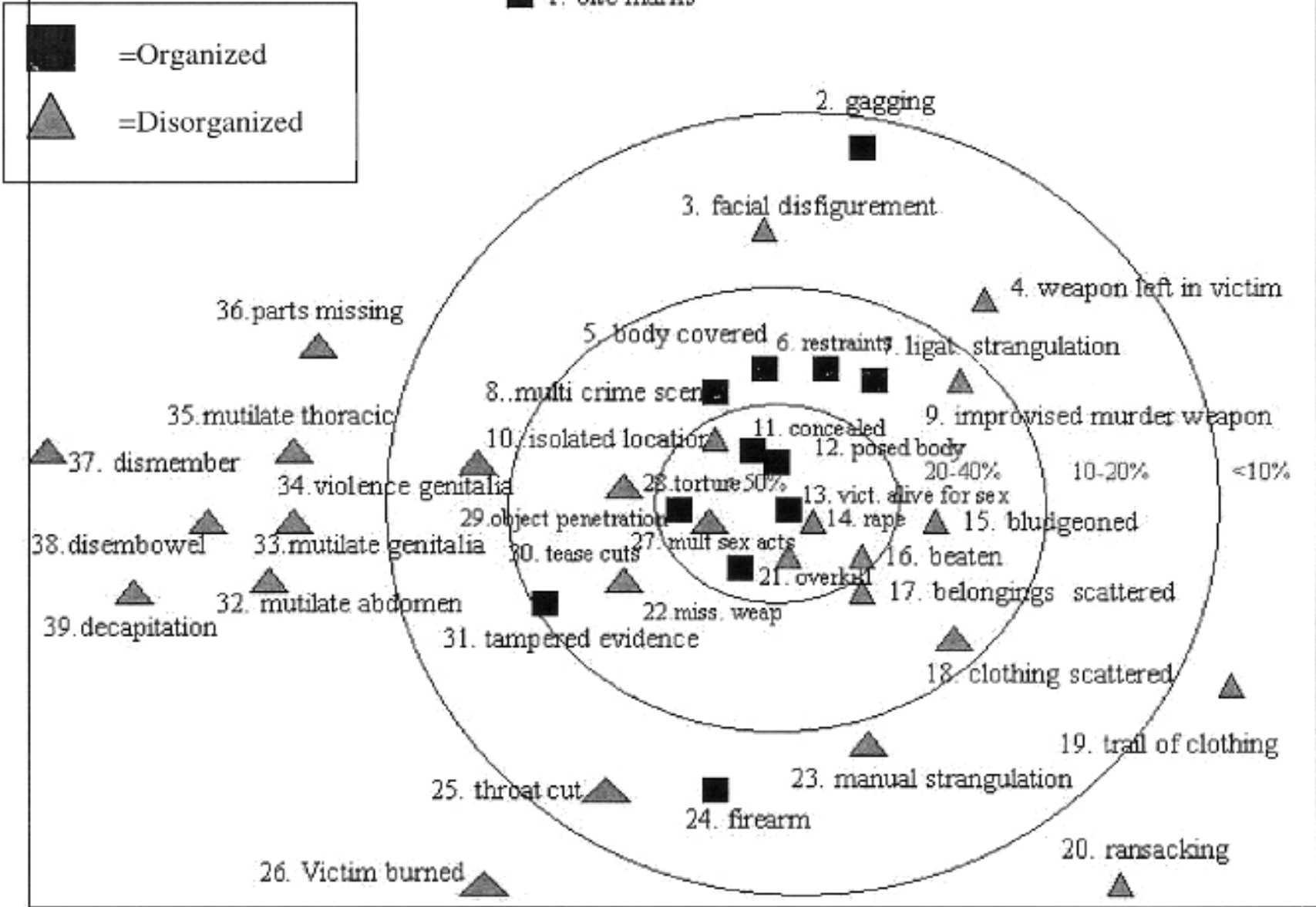

Gambar 1. Analisis lingkup terkecil dari 39 kriteria perilaku terorganisasi/tak terorganisasi (Kontur-kontur menunjukkan frekuensi keseluruhan).

Lilenfeld (dalam Cuvelier, 2001) menjelaskan, "You can usually tell [what pseudoscience is] because there's a lot of marketing around these treatments, but there's no controlled evidence. Support consists of almost all anecdotes and personal testimony".

Sejumlah argumen yang dikemukakan oleh pihak-pihak yang melihat pemrofilan kriminal sebagai pseudoscience bersesuaian dengan batasan Sarwono dan Lilenfeld di atas, sebagai berikut:

Pertama dan utamanya, terdapat kelemahan empiris metodologis dalam tipologi perilaku kriminal organized/disorganized yang sampai dengan saat ini digunakan secara luas dalam pemrofilan kriminal (Alison, Bennell, Mokros, \& Ormerod, 2002; Canter, Alison, Alison, \& Wentink, 2004; Gladwell, 2007; Snook, Cullen, et al., 2008).

Gladwell (2007) menggambarkan tipologi perilaku kriminal dikotomis organized/disorganized yang dihubungkan dengan kepribadian pelakunya, sebagai berikut:

Dalam sebuah tindak kriminal yang 'terorganisasi' (organized), kejahatan dilakukan secara logis dan terencana. Korban telah diburu (hunted) dan dipilih, guna memenuhi fantasi spesifik tertentu... Pelaku mengontrol seluruh proses kejahatan .... hampir tidak pernah meninggalkan senjatanya. Ia dengan sangat teliti menyembunyikan tubuh korban. Dalam tindak kriminal yang 'tidak terorganisasi' 
(disorganized), korban tidak dipilih secara logis. Korban nampaknya dipilih secara acak dan 'diserang secara kilat' (blitz-attacked), dan bukan diburu secara diam-diam dan diserang (stalked and coerced).... Tindakan kriminal dilaksanakan dengan sangat tidak rapi. Korban seringkali memiliki kesempatan melawan balik... Lebih dari itu, pelaku kejahatan tidak mengetahui atau berminat akan kepribadian dari korban mereka.... Masing-masing gaya ini [organized/disorganized] berkorespondensi dengan sebuah tipe kepribadian. Perilaku kejahatan yang terorganisasi dilakukan oleh seorang yang inteligen dan fasih, memiliki perasaan superior terhadap orang-orang di sekelilingnya. Sedangkan, perilaku kejahatan yang tak terorganisasi dilakukan oleh seorang yang tidak menarik (unattractive) dan memiliki citra diri yang buruk.

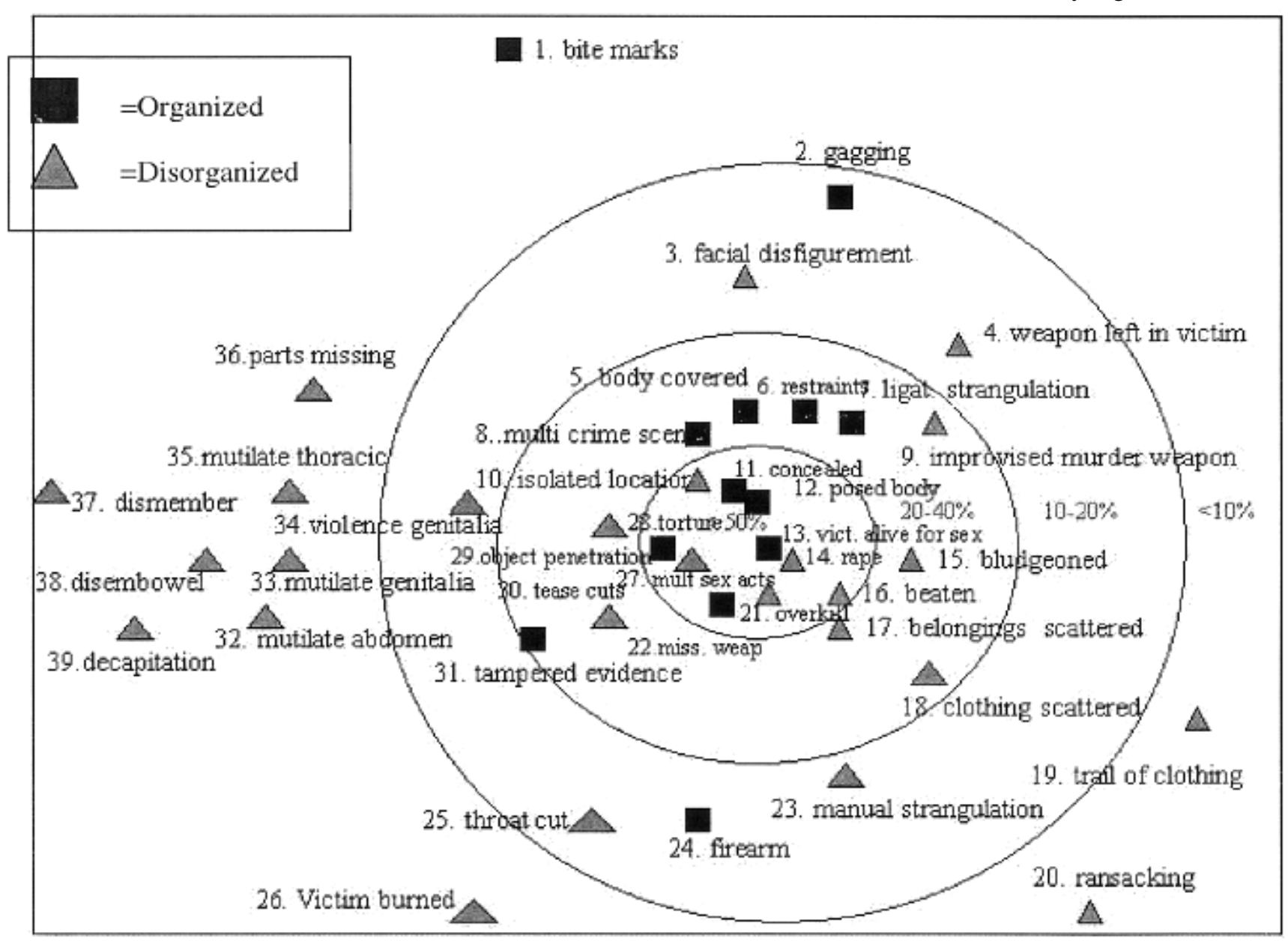

Gambar 2. Analisis lingkup terkecil dari 39 kriteria perilaku terorganisasi/tak terorganisasi yang menunjukkan empat gaya interaksi pelaku kejahatan dengan korban (Kontur-kontur menunjukkan frekuensi keseluruhan).

Melengkapi gagasan di atas, Douglas, Burgess, Burgess, dan Ressler (1992) menjelaskan:

Secara umum pelaku kejahatan terorganisasi diduga melakukan tindak kejahatan setelah mengalami beberapa peristiwa urgen yang penuh stres, seperti masalah finansial, masalah relasi antarmanusia, atau masalah pekerjaan.... Scene kejahatannya mencerminkan sebuah pendekatan yang metodis dan teratur. Hal ini dipandang sebagai konsekuensi dari pelaku kejahatan yang memiliki keterampilan 
sosial dan dalam menangnai situasi-situasi interpersonal. Pelaku kejahatan yang terorganisasi, dengan demikian, lebih mungkin menggunakan pendekatan verbal terhadap korban sebelum melakukan kekerasan .... Sebaliknya, pelaku kejahatan yang tak terorganisasi melakukan kejahatannya secara oportunistik. Ia tinggal dalam jarak yang dekat dengan scene kejahatan. Gaya penyerangannya spontan dan scene kejahatannya berada dalam situasi kaotik. Hal ini mencerminkan ketidakmampuan sosial dan ketidakterampilan interpersonal pelakunya.

Pendekatan tipologis dikotomis seperti di atas telah dikritik sebagai psikologi yang menyederhanakan (simplistic psychology) oleh Gladwell (2007). Alison et al. (2002) menyebut pendekatan tersebut sebagai naïve trait approach yang telah mengabaikan prinsip Person $x$ Situasi sebagai faktor-faktor interaktif dalam mempengaruhi suatu tindak kejahatan. Lagipula, Canter et al. (2004) telah menunjukkan melalui riset mereka terhadap arsip 100 kasus pembunuhan seksual serial-yakni pembunuhan yang melibatkan aktivitas seksual sebagai basis dari rangkaian aksi yang membawa pada kematian korban-di Pusat Psikologi Investigatif, Amerika Serikat, bahwa tidak terdapat suatu pola yang bersifat distingtif antara perilaku terorganisasi dan perilaku tak terorganisasi. Yang banyak terjadi (Canter et al., 2004) adalah koeksistensi kedua jenis perilaku tersebut (lihat Gambar 1), dan bahwa perilaku terorganisasi dan tak terorganisasi dapat terjadi dalam banyak varian gaya transaksional pelaku kejahatan dengan korban (lihat Gambar 2)_yang nampak "inkonsisten" satu dengan yang lain; misalnya, perilaku yang tak disorgnasasi di satu pihak dapat merupakan perilaku yang melibatkan mutilasi dan pengotoran (defilement) tubuh korban, namun, di lain pihak dapat pula merupakan perilaku yang menekankan perampokan (ransacking) dan perampasan (plundering) barang-barang kepunyaan korban. Selanjutnya, dalam banyak hasil penelitian, prediktor-prediktor perilaku kriminal yang sudah diakui secara luas dan kuat (misalnya, sikap dan kognisi antisosial) ternyata tidak berkaitan samasekali dengan jenis-jenis variabel yang selama ini difokuskan oleh pemrofil, seperti perilaku pada scene kejahatan-apakah terorganisasi, tak teroganisasi, atau campuran-dan demografi pelaku kejahatan (Snook, Cullen, et al., 2008).

Hal kedua yang menyebabkan orang mencurigai pemrofilan kriminal sebagai pseudoscience adalah karena keberhasilan pemrofil kriminal dalam membuat prediksi yang akurat mengenai pelaku kejahatan boleh jadi tidak berbasiskan pengetahuan spesialistik mengenai kekhasan dan keunikan (idiosyncrasies) yang terdapat pada scene kejahatan yang tengah dihadapi pemrofil (Snook, Cullen, et al., 2008). Dengan perkataan lain, dalam penelitian terkendali (controlled research), tidak dijumpai perbedaan yang signifikan antara kemampuan memprediksi antara pemrofil profesional dan yang bukan pemrofil. Polisi yang memiliki pengetahuan yang baik dalam hal kriminologi dapat pula mencapai tingkat keberhasilan pemrofilan kriminal semata-mata dengan mengandalkan informasi minimum standar (base rate).

Berdasarkan analisis kritisnya, Snook, Cullen, et al. (2008) menyimpulkan adanya dua faktor utama yang saling berinteraksi yang menyebabkan orang-orang meyakini keberhasilan pemrofilan kriminal, kendatipun tidak terdapat dasar-dasar teoritis dan dukungan empiris yang kokoh (pseudoscience). Faktor pertama adalah penyajian informasi tentang pemrofilan kriminal kepada masyarakat (aspek pesan/the message); faktor kedua adalah pemrosesan informasi tersebut oleh 
masyarakat (aspek pikiran/the mind). Yang termasuk faktor pertama, antara lain: (a) penekanan yang berlebihan terhadap kisah-kisah sukses sejumlah pemrofil yang telah memberikan profil akurat-yang secara prediktif telah membantu menyelesaikan investigasi kriminal yang sulit (hal ini diperkuat dengan anekdot-anekdot pada media massa), sementara kebanyakan kisah-kisah lain yang tidak sukses tidak diungkapkan, (b) pemaparan informasi secara repetitif bahwa pemrofilan kriminal merupakan alat investigatif yang efektif; hal ini diperkuat dengan sejumlah testimoni mengenai keberhasilan pemrofilan kriminal tertentu yang tidak divalidasi lebih lanjut secara empiris melalui riset, dan (c) adanya gejala heuristik keahlian (expertise heuristic). Pernyataan seorang pemrofil dipercaya karena ia menampakkan dirinya sebagai seorang ahli yang memiliki kemampuan dan pengetahuan istimewa (terlebih apabila ia pernah menjadi saksi ahli di pengadilan), memiliki pendidikan ilmiah formal serta pelatihan-pelatihan panjang dan akumulatif, sehingga mampu meramalkan karakteristik pelaku kejahatan secara akurat, dalam hal mana keahliannya diatribusikan lebih tinggi daripada keahlian rata-rata petugas kepolisian biasa atau orang-orang lain yang non-ahli.

Yang termasuk faktor kedua melibatkan proses-proses kognitif, antara lain: (a) ilusi korelasi dan bias konfirmasi. Dalam ilusi korelasi, orang mempersepsikan adanya hubungan antara prediksi pemrofil dengan terselesaikannya kasus kriminal, semata-mata karena sebuah profil kriminal telah diperoleh sebelum kasus terselesaikan (after-the-fact reasoning), padahal hubungan tersebut apabila diteliti sesungguhnya tidak ada. Dalam bias konfirmasi, orang mencari atau mengingat bukti-bukti konfirmatif (prediksi yang benar atau anekdot dalam literatur atau media populer) yang mendukung keyakinannya akan keberhasilan pemrofilan dan mengabaikan dan/atau melupakan bukti-bukti kontradiktif; (b) Efek Barnum (Barnum effect). Efek Barnum merupakan fenomena di mana orang cenderung menerima pernyataan-pernyataan ambigu, samar-samar dan umum sebagai deskripsi akurat atas kepribadiannya sendiri (Dickson \& Kelly, 1985). Dalam pemrofilan kriminal, ditemukan efek ini, bahwa keyakinan orang terhadap metode-metode pemrofilan kriminal dan keahlian pemrofil menjadi semakin positif setelah mereka dipapar dengan materi profil yang bersifat ambigu, meskipun secara aktual metode pemrofilan yang digunakan tidak valid dan pemrofilnya tidak benar-benar ahli; (c) penularan sosial (social contagion), dalam hal mana penggunaan pemrofilan kriminal yang diyakini efektif "ditularkan", misalnya, oleh FBI di Amerika Serikat, melalui program-program pelatihan, publikasi yang luas, tontonan televisi, dan sebagainya; dan (d) penyimpulan fakta berdasarkan fiksi, misalnya, fantasi pemrofilan (profiling fantasy), seperti tergambar dalam detektif-detektif fantastis, seperti Augueste Dupin, Sherlock Holmes, Hercule Poirot.

Kedua faktor tersebut saling berinteraksi membentuk suatu siklus, seperti yang digambarkan Kocsis (2006):

Popular culture representations and anecdotal testimonials may artificially elevate people's belief in the capabilities of profiling. These elevated beliefs may in turn lead to misconceptions concerning the accuracy and merit of criminal profiles. Such misconceptions may then in turn sponsor the continued use of profiling and perhaps lead to even more favorable media coverage and testimonials: thus the cycle continues. 
Jadi, keyakinan orang akan keberhasilan pemrofilan kriminal (keyakinan ini tidak harus berarti evidence-based) dipengaruhi oleh representasi mengenai "sukses" tersebut oleh media massa, dan selanjutnya, keyakinan tersebut berpengaruh terhadap frekuensi dan intensitas penggunaan pemrofilan kriminal, dan seterusnya.

Yang patut dicermati dalam kaitan dengan seluruh uraian di atas adalah bahwa terdapat satu istilah yang tidak muncul dalam tulisan Snook, Cullen, et al. (2008) yang mengkritik pemrofilan kriminal sebagai pseudoscience, yakni "protoscience". Padahal, menurut penulis, pengertian mengenai protoscience sangat krusial dalam pertimbangan klasifikasi apakah sesuatu itu science ataukah pseudoscience, utamanya dalam perspektif prospektif. Secara ringkas, Gay (2008) mendefinisikan protoscience sebagai "emerging science establishing its legitimacy". Sudah sejak 1959, Karl Popper menggunakan istilah protoscience secara konseptual sebagai:

A hypothesis that has not yet been adequately tested by the scientific method, but which is otherwise consistent with existing science or which, where inconsistent, offers reasonable account of the inconsistency. It may also describe the transition from a body of practical knowledge into a scientific field.

Hal ini bukan berarti bahwa suatu teori yang bertentangan dengan satu atau dua teori sebelumnya otomatis tergolong dalam pseudoscience. Namun, sebuah protoscience atau science, walaupun bertentangan dengan teori-teori tertentu, ia masih cocok dengan sejumlah teori lainnya. Hal ini sesuai dengan norma koherensi (norms of coherence) yang merupakan determinan baiktidaknya suatu teori (Shaw \& Costanzo, 2002). EMDR (Eye Movement Desensitization and Reprocessing) adalah sebuah contoh yang baik dari penyelewengan fundamental yang serius terhadap norma koherensi itu: "The theory of EMDR clashes with scientific knowledge of the role of eye movements" (Barret, 2003). Berkebalikan dengan protoscience, pseudoscience dikonsepkan sebagai "...theories which are either untestable in practice or in principle, or which are maintained even when tests appear to have refuted them" ("Pseudoscience," 2009).

Apabila penjelasan di atas dikaitkan dengan pemrofilan kriminal, maka nampaknya masih tersisa ruang bagi pemrofilan kriminal untuk menyandang status sebagai sebuah sains di masa mendatang. Terdapat sedikitnya dua alasan yang dapat menerangkannya:

Pertama, pembedaan yang dilakukan oleh Canter et al. (2004)—sebagaimana juga terungkap sebelumnya di atas-antara core variables dan bukan core variables yang sama-sama penting dan berguna dalam proses pemrofilan kriminal sebenarnya lebih merupakan upaya penyempurnaan teori tipologis organized/disorganized yang dipandang usang dan memiliki kelemahan. Di samping itu, pemrofilan kriminal juga konsisten dengan body of knowledge yang pernah ada sebelumnya yang relevan, yakni Prinsip Pertukaran dari Locard (Chisum \& Turvey, 2000; Turvey, 1995). Prinsip pertukaran ini menyatakan bahwa siapa pun yang memasuki scene kejahatan, maka ia mengalami dua hal sekaligus, yakni mengambil sesuatu dari scene tersebut dan meninggalkan sesuatu pada scene yang membekas/menjejak dari dirinya. "Sesuatu" yang dimaksud adalah benda fisik. Telah ditunjukkan melalui sejumlah penelitian (dalam Turvey, 1995), bahwa percabangan 
psikologis (baca: pengembangan) dari prinsip Locard, dalam rupa aplikasi prinsip-prinsip psikologis (fantasi, disasoisasi, pengendalian, reenactment, empati, intimasi, analisis perilaku, dan lain-lain) terhadap bukti-bukti fisik, telah menunjukkan hasil yang mumpuni, meskipun harus memenuhi syarat-syarat tertentu yang ketat.

Secara operasional, Gay (2008) pernah memberikan dua puluh empat pertanyaan — sebagai modifikasi dari dua belas pertanyaan Moller (1989) — guna membantu membedakan pseudoscience dari protoscience. Moller (1989) sendiri menempatkan pertanyaan, “Apakah subjek/disiplin yang dibahas menunjukkan adanya kemajuan?" (Has the subject shown progress?) pada urutan pertama, kalau bukan yang terpenting. Ia menjelaskan:

Banyak ilmu-ilmu semu telah ada lama sekali namun menunjukkan kemajuan yang sedikit, kalau bukan tidak ada kemajuan sama sekali. Contoh yang baik dalam hal ini adalah grafologi (analisis tulisan tangan). Ada sejumlah teori grafologi sepanjang abad belakangan ini, dan semua teori tersebut sama-sama lemahnya....

Bahkan, grafologi telah masuk dalam daftar subjek yang terdapat pada The Encyclopedia of the Paranormal (Beyerstein, 2002). Namun demikian, apabila indikator Moller (1989) dikenakan pada pemrofilan kriminal, maka, dengan memperhatikan kemajuan-kemajuan yang dicapai oleh pemrofilan kriminal di atas, jawaban "ya" dapat diberikan pada pertanyaan Moller. Terlebih lagi, jawaban positif ini dapat diperkuat dengan pengakuan Snook, Cullen, et al. (2008) sendiri, bahwa:

.... there are signs that progress is being made. Several individuals are attempting to develop criminal profiling classification systems and are going through the steps required to validate those systems (e.g., Häkkänen, Lindof, \& Santilla, 2004; Kocsis, 2006; Salfati, 2000). Others are taking a bottom-up approach to profiling by identifying individual behavior-offender associations and the condition in which these will arise (e.g., Goodwill \& Alison, 2007). However, this research is in its infancy and the typologies emerging are still not used widely in criminal profiling circles. Unfortunately, that role is currently taken up by classification systems that are not largely supported by psychological science.

Hal kedua, dalam kaitannya dengan realitas pemrofilan yang sudah dikemukakan di atas, pendapat Koentjoro (2008) yang mengambil inspirasi epistemologis Kantian mengenai jenis-jenis realitas sosial dapat dirujuk. Menurutnya, ada dua jenis realitas sosial, yaitu phenomena dan noumena. Phenomena adalah realitas sosial yang dapat kita observasi, realitasnya eksis, dan dapat dijelaskan secara rasional. Sedangkan, noumena adalah realitas sosial yang dapat kita observasi, realitasnya ada, namun belum mampu dijelaskan secara rasional (misalnya, kesurupan masal). Hal ini bukan berarti bahwa noumena tersebut tidak rasional, namun otak manusia belum mampu menjelaskan secara rasional (contoh: di tahun 1950-an, televisi tanpa kabel, mesin cetak jarak jauh, dan sebagainya, mungkin dianggap banyak orang sebagai tidak rasional); dan mungkin saja suatu saat noumena akan menjadi rasional. Dalam hal bahasan tulisan ini, dapat dikatakan bahwa pemrofilan kriminal sesungguhnya berada dalam ketegangan antara noumena dan phenomena. Dengan berkembang pesatnya studi-studi ilmiah mengenenainya, pemrofilan kriminal semakin progresif menuju pada sifat phenomenal yang dapat diterangkan secara ilmiah. 
Demikianlah sesungguhnya terdapat harapan bahwa pemrofilan kriminal merupakan protoscience yang suatu waktu dapat dikembangkan sebagai science. Harapan ini dapat semakin diperkuat apabila kita mencoba menjawab pertanyaan lain yang diajukan Gay (2008), “Can you find relevant papers authored by the proponents in the relevant refereed scientific literature (e.g., such as on Medline Pubmed for medical subjects)?" Penelusuran penulis terhadap sejumlah pangkalan data jurnal ilmiah setidaknya menunjukkan hasil-hasil yang jauh lebih positif dalam rangka memberikan jawaban yang optimistis terhadap pertanyaan tersebut dengan kata kunci "criminal profiling" daripada, misalnya, "graphology", "handwriting analysis", "brain gym", dan sejenisnya. Selanjutnya, lebih banyak ditemukan hasil-hasil temukembali yang mutakhir sekaligus apresiatif-ilmiah terhadap pemrofilan kriminal daripada terhadap contoh-contoh ilmu dan praktek yang telah diidentifikasikan sebagai pseudoscience sepanjang tulisan ini.

\section{Kesimpulan dan Saran}

Pemrofilan kriminal merupakan sebuah alat forensik yang dapat dipelajari dan digunakan oleh siapa saja, termasuk oleh psikolog forensik. Kompetensi dalam psikologi ternyata turut memegang peran penting dalam sukses atau tidaknya pemrofilan kriminal. Sejauh ini, banyak profesi telah mengambil manfaat-menurut persepsinya masing-masing — dari pemrofilan kriminal, termasuk profesi kesehatan mental, seperti psikolog dan psikiater. Kendati demikian, popularitas aplikasi pemrofilan kriminal tidak serta-merta menunjukkan bahwa disiplin ini sudah jelas dan kuat kedudukan keilmuannya. Berdasarkan seluruh uraian di atas nampak bahwa status ilmiah pemrofilan kriminal sampai dengan saat ini masih "kontroversial". Menurut penulis, kontroversi tersebut lebih disebabkan karena tarik-menarik perspektif untuk mengambil posisi apakah pemrofilan kriminal saat ini sesungguhnya merupakan protoscience ataukah pseudoscience, dan bukan dalam hal penggolongan kedalam ranah dikotomis "atau pseudoscience atau science".

Pemrofilan kriminal, dan disiplin psikologi forensik lainnya-seperti yurisprudensi terapeutik (Juneman, 2008)—khususnya di Indonesia, belum memperoleh penghargaan yang layak. Namun demikian, penulis telah menunjukkan bahwa pemrofilan kriminal memiliki peluang dan masa depan untuk tumbuh dan berkembang sebagai sebuah ilmu psikologis, dan bahwa hal ini perlu dikawal dengan sikap dan penggunaan kritis terhadap pemrofilan kriminal secara berkelanjutan. Di samping itu, apabila pemrofilan kriminal hendak berjaya, hal-hal berikut perlu dipertimbangkan: (a) melakukan penelitian-penelitian lebih lanjut (search and re-search) yang berkenaan dengan validitas dan reliabilitas dari pemrofilan kriminal, (b) di era teknologis global sekarang ini, sudah saatnya pemrofil turut menggunakan program komputer dengan sistem fuzzy logic yang mampu menangani beragam dimensi [non-linear] dari pemrofilan kriminal (lihat, misalnya, "Match'em: Using," 2002); dalam hal ini, penelitian validitas pemrofilan dapat juga diteliti secara masif, serta (c) pemrofilan kriminal sebagai bagian dari penegakan hukum hendaknya dipahami dalam perspektif yang jauh lebih visioner. Maksudnya, pemrofilan kriminal tidak hanya bertujuan mendeteksi, memahami suatu peristiwa kejahatan, tetapi juga menurunkan tingkat kejadian kejahatan atau berfungsi preventif (Cook \& Hinman, 1999; Harcourt, 2007). Hal ini mengingat bahwa kedua tujuan tersebut dapat berkonflik atau bersifat paradoksal, sebagaimana ditunjukkan oleh Harcourt (2007: 124). Oleh karena itu, di samping pemrofilan kriminal itu sendiri perlu 
direvisi secara kontinu guna memenuhi secara memuaskan tujuan pertama, maka perlu adanya semacam jembatan proses atau aktivitas pengiring agar tujuan kedua juga tercapai.

\section{Bibliografi}

Alison, L., Bennell, C., Mokros, A., \& Ormerod, D. (2002). The personality paradox in offender profiling: A theoretical review of the processes involved in deriving background characteristics from crime scene actions. Psychology, Public Policy, and Law, 8(1), 115-135.

Barrett, S. (2003). Mental help: Procedures to avoid. Ditemukembali pada 18 Februari 2009, dari http://www.quackwatch.org/01QuackeryRelatedTopics/mentserv.html

Beyerstein, B. L. (2002). How graphology fools people. Ditemukembali pada 18 Februari 2009, dari http://www.quackwatch.org/01QuackeryRelatedTopics/Tests/grapho.html

Canter, C. (2003). Mapping murder: The secrets of geographical profiling. UK: Virgin Books.

Canter, D. V., Alison, L. J., Alison, E., \& Wentink, N. (2004). The organized/disorganized typology of serial murder: Myth or model? Psychology, Public Policy, and Law, 10(3), 293320.

Carrol, R. T. (2009). From abracadabra to zombies: Eye movement desensitization and reprocessing (EMDR). The Skeptic's Dictionary. Ditemukembali pada 18 Februari 2009, dari http://skepdic.com/emdr.html

Chisum, W. J., \& Turvey, B. E. (2000). Evidence dynamics: Locard's exchange principle \& crime reconstruction. Journal of Behavioral Profiling, 1(1).

Cook, P. E., \& Hinman, D. L. (1999). Criminal profiling: science and art. Journal of Contemporary Criminal Justice, 15, 230-241.

Cuvelier, M. (2001). The pursuit of pseudoscience. Psychology Today, Jul/Aug 2001, Article ID: 2141. Ditemukembali pada 18 Februari 2009, dari http://www.psychologytoday.com/articles/pto-20010701-000014.html

Dickson, D. H., \& Kelly, I. W. (1985). The Barnum Effect in personality Assessment: A review of the literature. Psychological Reports, 57, 367-382.

Douglas, J. E., Burgess, A. W., Burgess, A. G., \& Ressler, R. K. (1992). Crime classification manual: A standard system for investigating and classifying violent crime. New York: Simon and Schuster.

Gay, J. (2008). Veterinary medicine and the philosophy of science. Ditemukembali pada 18 Februari 2009, dari http://www.vetmed.wsu.edu/courses-jmgay/EpiPhil.htm

Gladwell, M. (2007). Dangerous minds. The New Yorker; Dept. of Criminology, 83(35), 36.

Goldacre, B. (2006). Brain gym: Name \& shame. Ditemukembali pada 18 Februari 2009, dari http://www.badscience.net/2006/03/the-brain-drain/

Harcourt, B. E. (2007). Against prediction: Profiling, policing, and punishing in an actuarial age. USA: University of Chicago Press.

Hartman, S. E., \& Norton, J. M. (2002, November). Craniosacral therapy is not medicine. Phys Ther, 82(11), 1146-1147. Ditemukembali pada 18 Februari 2009, dari http://www.ptjournal.org/cgi/content/full/82/11/1146 
Heider, F. (1958). The psychology of interpersonal relations. New York: Wiley.

Horswell, J. (Ed.). (2004). The practice of crime scene investigation. London: CRC Press.

Juneman. (2008). Yurisprudensi terapeutik: Peran integratif psikologi dalam proses hukum untuk melayani kesejahteraan pribadi klien hukum. Jurnal Kajian Ilmiah Universitas Bhayangkara Jakarta Raya, 9(3), 908-922.

Kocsis, R. N. (2006). Criminal profiling: Principles and practice. New Jersey: Humana Press.

Koentjoro. (2008). Materi kuliah metode penelitian kualitatif. Tidak diterbitkan.

Match'em: Using fuzzy logic to profile criminals. (2002). Ditemukembali pada 18 Februari 2009, dari http://ieeexplore.ieee.org/xpl/freeabs_all.jsp?arnumber=616386

Moller, L. (1989). Pseudoscience or Protoscience? The Newsletter of The North Texas Skeptics, 3(3). Ditemukembali pada 18 Februari 2009, dari http://www.ntskeptics.org/1989/1989mayjune/mayjune1989.htm

National Council Against Health Fraud. (2001). Pseudoscientific psychological therapies scrutinized. NCAHF news, 24(4). Ditemukembali pada 18 Februari 2009, dari http://www.ncahf.org/nl/2001/7-8.html

O'Toole, M. E. (1999). Criminal profiling: The FBI uses criminal investigative analysis to solve crimes. Corrections Today, 61(1), 44-46.

Penyebab tewasnya David ditentukan Coroner Court. (2009). Kompas.com. Ditemukembali pada 22 Maret 2009, dari http://internasional.kompas.com/read/xml/2009/03/19/1420565/Penyebab.Tewasnya.David.Dite ntukan.Coroner.Court

Petition for the recognition of police psychology as a proficiency in professional psychology. (2008). Ditemukembali pada 18 Februari 2009, dari http://www.apa.org/crsppp/APA\%20Police\%20Psychology\%20Proficiency\%20PetitionFinal.pdf

Popper, K. R. (1959). The logic of scientific discovery. Tenth Impression (Revised) 1980. London: Hutchinson.

Pseudoscience. (2009). Wikipedia. Ditemukembali pada 18 Februari 2009, dari http://en.wikipedia.org/wiki/Pseudoscience

Ramsland, K. (2008). Criminal profiling: Part 1 history and method. Ditemukembali pada 18 Februari 2009, dari http://www.trutv.com/library/crime/criminal_mind/profiling/history_method/new_22.html

Rogers, M. (2003). The role of criminal profiling in the computer forensics process.

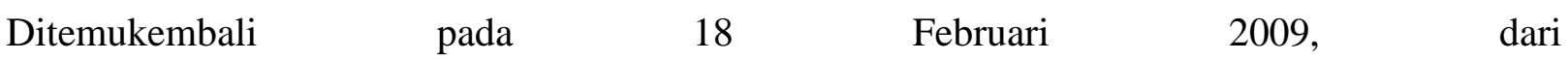
http://www2.tech.purdue.edu/cit/Courses/CIT556/readings/Profile-Rogers.pdf

Sarwono, S. W. (2000). Berkenalan dengan aliran-aliran dan tokoh-tokoh psikologi. Jakarta: Bulan Bintang.

Shaw, M. E., \& Costanzo, P. R. (2002). Teori-teori psikologi sosial (Sarlito W. Sarwono, Penerj. \& Peny.). Jakarta: RajaGrafindo Persada. (Karya asli diterbitkan tahun 1970)

Sherrer, H. (2004). That's not my fingerprint, your honor. Justice: Denied, 25, 11. Ditemukembali 
$\begin{array}{lllll}\text { pada } & 18 & \text { Februari } & 2009, & \text { dari }\end{array}$ http://www.justicedenied.org/issue/issue_25/brandon_mayfield.html

Snook, B., Gendreau, P., Bennell, C., Taylor, P. J. (2008). Criminal profiling. Skeptic, 14(2), 4247,80 .

Snook, B., Cullen, R. M., Bennell C., Taylor, P. J., \& Gendreau, P. (2008). The criminal profiling illusion: What's behind the smoke and mirrors? Criminal Justice and Behavior, 35, 1257-1276.

Student stabs prof, jumps. (2009). The Strait Times Discussion Board. Ditemukembali pada 6 Maret 2009, dari http://comment.straitstimes.com/showthread.php?t=17387\&page=15

Turvey, B. E. (1995). The Impressions of a man: An objective forensic guideline to profiling violent serial sex offenders. Ditemukembali pada 18 Februari 2009, dari http://www.criminalprofiling.ch/article1.html

Turvey, B. E. (2008). Criminal profiling: An introduction to behavioral evidence analysis ( $3^{\text {th }} \mathrm{ed}$.). London: Academic Press.

Webb, D. (2006). What is forensic psychology? All about forensic newsletter 2. Ditemukembali pada 18 Februari 2009, dari http://www.all-about-forensic-psychology.com/what-is-forensicpsychology.html

Winerman, L. (2004). Criminal profiling: the reality behind the myth. Monitor on Psychology, $35(7), 66-69$. 

